too quick to condemn her. For years the insurance companies have been conducting an advertising campaign stressing the "savings" characteristic of insurance. ${ }^{29}$ By pressing the whole-life, 20-pay life, and 20 year endowment policies, they have encroached on the business of savings banks. ${ }^{30}$ LISA may be a portent that the banks will reverse the procedure and enter the insurance business. Perhaps this fight between the financial giants ${ }^{31}$ will prove beneficial to the public, which continues to hope that one day large insurers will become conscious of their obligation to provide inexpensive plans of real life insurance. Ironically, savings banks are the only ones to offer these desirable plans, in the few states in which they have been able to overcome the tremendous resistance offered by powerful competitors. ${ }^{\text {22 }}$ Harry P. Glassman

\title{
SOME PROPOSALS FOR MODERNIZING THE LAW OF ARREST
}

One of the most important junctures at which Citizen meets Law is in the course of the transaction known as "arrest." 1 Yet, ordinarily, lawyers -even criminal lawyers - know little of how the law of arrest is given effect by the vastly-important individual who uses it most: the cop on the beat.

Since the endless process of legal adjustment and reform is customarily accomplished, to whatever extent it is accomplished, by legally-trained persons, their lack of contact with the facts of arrest may be at least one of the reasons that occasional attempts by legal scholars to investigate this no-lawyer's-land of the prevention of crime and the apprehension of criminals have revealed some rather striking inconsistencies between what the written law of arrest says and what those who make virtually all the arrests in this country do. ${ }^{2}$ If that is so, it might be well indeed if more lawyers would give this subject somewhat more attention.

That techniques employed by police officers in California have, in some

29 "The bigger the investment-feature in the policy, the less insurance in the policy-the more eloquent is the sales-talk. Hence we are led to the remarkable conclusion that life insurance is an institution marked by a peculiar aversion to selling life insurance." GILBERT, op. cil. supra note 25 , at 121 .

30 The assets of life insurance companies are greater than deposits in the nation's savings banks and savings and loan associations. 37 ForTurre 101 (April 1948).

31 The effect upon our economy of the investment of the tremendous assets of the insurance companies has presented an important problerm. See Comment, 57 YaLE L. J. 1256 (1948).

32 In nearly every state in the nation, the insurance companies lave exerted great pressure and spent large suins of money to fight savings bank insurance. See GeSELL AND HowE, STUdY of Legal Reserve LIFe Insurance Companies (TNEC Monograpl 28, 1940); Statement on LTFE INSURANCE (TNEC Monograph 28-A, 1941).

1 The Adult Authority estimates that there are upward of 600,000 arrests a year in California for criminal offenses other than traffic violations. Of these, 100,000 are for felonies and 500,000 for misdemeanors.

2 Smith, Police Systeass In the United States 10-14, 341-343 (Rev. Ed., 1949); Waite, The Law of Arrest, 24 Texas L. Rev. 279 (1946); Warner, Investigating the Law of Arrest, 26 A. B. A.J. 151 (1940) ; Hall, Law of Arrest in Relation to Contemporary Social Problems, 3 U. OF CEI. L. Rev. 345 (1936) ; Yankwich, The Lawless Enforcement of the Law, 9 So. CauIf. L. Rev. 14 (1935); Natronal Commission on LAw Observance and ENForcement: Report No. 11: LAwLESSNESS IN LAW ENFORCEMENT (June 25, 1931); Waite, Some Inadequacies in the Law of Arrest, 29 Mich. L. REv. 448 (1931). 
technical respects, outrun the written law need come as no great surprise when it is noted that the pertinent statutes ${ }^{3}$ have not been materially altered since $1872 .^{4}$ The one statute which has been amended repeatedly, with great effect on the techniques of arrest, the vagrancy statute, is not a procedural provision but a substantive one. ${ }^{5}$ In the years since 1872 , a number of inventions have had considerable impact on the techniques of law-breaking and law enforcement. ${ }^{6}$ Properly viewed, the California law of arrest is a good deal older than 1872 , since it is based almost completely and literally on provisions of the proposed code of criminal procedure reported to the New York legislature in $1850,{ }^{7}$ which, in turn, has its roots far back in the

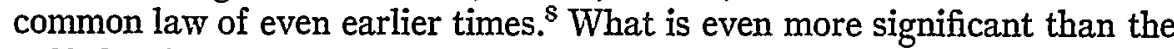
gulf that lies between the arrests of 1872 and the technologically complicated world of 1951 is the emergence, since the days when the rules were being evolved, of vastly expanded structures of organized crime on the one hand ${ }^{9}$ and professional law enforcement agencies on the other. "The law of arrest ... not only antedates the modern police department, but was developed largely during a period when most arrests were made by private citizens." 11

In view of these facts, the police forces of California deserve to have

3 CAT. Pen. Code $\$ \$ 811-829,834-851,852-852.4 ; 854-855 ; 142,145,147-150,196$, and 825.

4 Fifteen of the most important sections on arrest, $834-851$, have not been altered since their adoption in 1872. The other four have'been subject to very shight changes and rearrangements of words with no effect on the substance. Section 852, UNIFORM ACT ON FrESH PURSUIT, was adopted in 1937.

5 CAL. PEN. CODE $\$ 647$, which enumerates who are vagrants and prescribes penalties, has been amended eight times. The most important changes were those in 1891 and 1903, by which some of the broadest categories were set up. The Special Crime Study Commission on Criminal Law and Procedure, in its report dated June 30,1949, recommends that this section be studied to deterunine whether the present enumeration of persons included is complete or whether certain classes should be eliminated. See Grossman, Who Is a Vagrant in California?, 23 CALIF. L. REv. 506 (1935), criticizing the present broad wording of the statute because of the possibilities of abuse, and Ames, $A n$ Answer, 23 CALIF. L. REv. 616 (1935), justifying the statute because of its practical usefulness in police operations.

It is one of the arguments of the present comment that modernizing the procedural rules concerning arrest would make it unnecessary to cover so many police actions by the use of the vagrancy statute, and the very real possibilities for abuse discussed in the Grossman note could be ehiminated through amendment without impairing police efficiency.

6 Burglar alarm systems (1872), telephone (1876), electric light (1879-1880), automobile (c. 1891), radio (c. 1892), flashlight (1898), airplane (c. 1903), teletype (c. 1914), police radio (1933), television (c. 1927).

7 Fourte Report of the Commissioners on Practice and Pleadings: Code of Crimtinat Procedure \$\$ 158-179.

S Stephen, Digest of Procedure, Arts. 96-107 (1883).

- See Final Repigrt of the Spectat Crmat Study Comomission on Organtzed Crmie (November 15, 1950).

10 Of three California police departments giving information on the point, one guessed that $5 \%$ of its bookings were cases of arrest by private citizens-almost all in situations of battery or disorderly conduct; see text at note 45 infra. Another department said that the number of citizen's arrests was so small as to be statistically negligible. The third said there were no citizen's arrests; this is probably a matter of defimition, since there were undoubtedly battery and disorderly conduct situations such as those referred to above.

11 Warner, The Uniform Arrest Act, 28 VA. L. REv. 315 (1942); see LEE, A History of Pource IN England cc. 10-12 (London, 1905); Hall, Legal and Social Aspects of Arrest Without a Warrant, 49 HARv. L. REv. 566, at 578-90 (1936). 
the law in this field examined and overhauled with due regard to the anachronism of attempting to impose 19th century arrests on 20th century criminals. ${ }^{12}$ Obviously, a thorough investigation by a group or agency with the power to elicit the pertinent information, weigh it judiciously, and implement the resultant recommendations is desirable. ${ }^{13}$ It can only be attempted here to consider what some legal scholars and some California police departments have designated as crucial points, together with suggestions that have been made for statutory changes at those points. ${ }^{14}$ In attempting to judge the merits of proposed revisions, consideration has not been confined to the points at which police practice may deviate from strict conformity to statutory rules governing arrest. All proposals deserve careful attention, even where it has been possible, though not always fully efficient, for the police to operate within legal limits, for it is clearly not desirable that police departments must break the law before legislators will take note of their problems.

The law of arrest consists of rules dealing principally with:

(1) Definitions of arrest.

(2) Limitations on right to arrest, varying with:

(a) the individual nuaking the arrest (police officer or private citizen),

(b) the time of arrest in relation to the type of offense,

(c) whether the arrest is with or without warrant.

(3) Linitations on manner of making the arrest.

(4) The issuance of warrants.

(5) Duties of officer or private person after making the arrest.

12 “. . . by reason of the radical changes which have taken place in the political and economic be of the State since 1872 , when the basic Iaw was enacted, a certain comprehensive revision of the law was indicated. For it is plain to see that a system of penal statutes adequatc for an agricultural and mining community of small population cannot be wholly satisfactory for a coumonwealth boasting a population of some ten million people, most of them living in crowded industrial communities. When our Penal Code was adopted, we had no automobiles, no airplanes, no radios, no freeways, and none of the things we are pleased to call inprovements of modern civilization." Introduction to FINAL REPORT OF THE SPECIAL CrnME StUdy Commission on Criaminal Law and Procedure 8 (June 30, 1949).

The reports of this Counmission and its predecessors since 1925 have resulted in many inportant and salutary reforms in California criminal law, penal system, and judicial procedures; but to date none has considered the possibility of making law enforcement more effcctive through revision of the rules governing arrest.

13 Questionnaires asking for opinions on certain proposed statutory revisions and the experience on which those opinions were based were inailed to police chiefs of the twenty largest California cities in preparation for this comnent. Five replies were received, all from cities among the first ten in population, three of which contained answers to the questionnaires. Further interviews and consultations with police chiefs, police officers, a district attorney, and various scholars of criminal law supplemented this somewhat meager response. Since some of the information thus received involves police practices which might subject the various departments to destructive criticisun if it were possible to attach it to its source, none of these agencies or individuals is identified. Statements in the comment which are based on material obtained in this way are fairly clearly indicated to be froun such sources. Despite the necessary anonymity of those who cooperated, the author wishes to express his most sincere thanks to them.

14 Most of the proposals come from Tre UnIFOrM ARREST Acr promulgated by the Interstate Commission on Crime as a result of discussions and investigations made in 1939. Sam Bass Warner, then Professor of Law at Harvard University, was the reporter and the full text of the Act, together with his explication of its provisions appears in The Uniform Arrest Act, 28 VA. L. REv. 315 (1942). Other sources of proposals were Hall, supra note 2; Waite, supra note 2; and suggestions made by various police departments and individuals. 
(6) The effects of

(a) illegal arrest, or

(b) violations of duties after arrest. ${ }^{15}$

At least twelve crucial points have elicited suggestions for revision. They distribute themselves under every one of the major headings in this classification. ${ }^{16}$ Here is persuasive evidence that a general review rather than haphazard timkering is needed.

\section{Detention for Questioning}

The most important question arising in the consideration of how arrest is to be defined ${ }^{17}$ is the distinction, if any, to be made between an arrest and a brief detention for questioning. Undoubtedly this is one of the points at which law and practice deviate sharply. ${ }^{18}$

Except where an offense has been committed in an officer's presence, arrest without a warrant is legal only where there is "reasonable cause" to believe the person arrested has committed a felony. ${ }^{19}$ Thus, a person who refuses to answer questions or to stop long enough to be asked them cannot legally be arrested if his conduct and the surrounding circumstances are only such as to create suspicion rather than affording reasonable grounds for belief in his guilt. ${ }^{20}$ And, according to the general rule ${ }^{2 x}$ and, on its face,

15 The classification represents a slight modification of that made by Hall, in Legal and Social Aspects of Arrest Without a Warrant, 49 HARv. L. REv. 566 (1936).

10 Under (1), Detention for Questioning and Requiring Witnesses to Give Information; under (2)a, Refusing to Arrest on Citizen's Charges; under (2)c, Felony-Misdemeanor Problems and Extended Use of Summons and Citation; under (3), Right to Search for Deadly Weapons, Permissible Use of Force, and Taking Away Right to Resist Arrest; under (4), Arresting Without Possession of Issued Warrant; under (5), Permissible Delay in Producing Before a Magistrate and Legalizing Release without Appearance before a Magistrate; and under (6), False Arrest Suits.

15 CAL. Pen. Code $\$ \$ 834,835$.

18 Where one of the departments responding to the questionnaire estimated the number of people stopped for questioning as compared to those actually arrested by officers on beat and patrol as about 5 to 1 , another placed it at 95 to 1 ! The latter department has an excellent reputation for calibre of personnel and techniques of operation. Thus, a low ratio, while indicating less "illegality," may actually signify a greater predilection to arrest on slight pretexts. As pointed out by one of the responding departments, the ratio varies greatly from beat to beat and district to district, and is further dependent upon whether normal or abnormal crime conditions exist at any given time and place.

19 Cal. Pen. Code $\$ 836$ (2), (3), (4), and (5).

20 At least such is the prevailing rule. See 6 C.J.S. 598, n. 92 , for copious annotation. However, the case law in California is not entirely clear on the point. In People v. Kilvington, 104 Cal. 86, 92, 37 Pac. 799, 801 (1894) the court quoted with approval from Bacon v. Towne, 4 Cush. 217: "There must be such a state of facts as would lead a man of ordinary care and prudence to beheve, or entertain an honest and strong suspicion, that the person arrested is guilty' of the offense charged." (Emphasis added.) To the same effect is People v. Melendrez, 129 Cal. 549, 62 Pac. 109 (1900). In Cook v. Singer Sewing Machine Co., 138 Cal. App. 418, 421,32 P.2d 430, 431 (1934) it was stated that belief rather than suspicion is required; but in People v. Brite, 9 Cal. 2d 666, 687, 72 P. 2d 122, 133 (1937) the supreme court confused the issue nicely by saying that "probable cause is a suspicion founded upon circumstances sufficiently strong to warrant a reasonable man in the belief that the charge is true." Apparently, where "reasonable men" may believe, officers are warranted in suspecting. The implication that officers are somewhat less bright than "reasonable men" seems, at the very least, uncharitable. But see People v. Hupp, 61 Cal. App. 2d 447, 449, 143 P.2d 84, 85 (1943) ("honest and strong suspicion.")

21 Voorheses, The Law of ARrest 78 (2d ed. 1915). 
the controlling statute in California, ${ }^{22}$ he cannot lawfully be detained for questioning if he does not choose to be so questioned, without effecting an actual arrest. Yet detention for questioning ${ }^{33}$ is not only practiced; it constitutes an overwhelmingly large proportion of beat and patrol officers' activity. ${ }^{24}$ Without it, the number of cases successfully "closed" would probably diminish to the point of invisibility.

Several things may result if the suspect will not cooperate: (1) the officer may "bluff" the suspect with threat of arrest on real or fictitious charges ${ }^{25}$ even though it is generally held that where one is detained by an officer through express or implied threats an actual arrest has been made; (2) the officer may arrest on an actual, but irrelevant, charge; ${ }^{26}$ or (3) the officer may shrug his shoulders in cynical frustration and let a person whom there is some ground to suspect of a crime go free.

At least one large police department in the state believes that the right to question is supported by judicial decision, apparently having in mind the case of Gisske v. Saunders. ${ }^{27}$ The facts of that case present a typical example of the sort of belligerent stalemate that frequently results because of the uncertainty of rules governing situations like these; and they also cast some doubt on the case as justifying the right to detain and question. A burglary and highway robbery had been committed in a certain neighborhood. The defendant officer was notified that a suspicious character was in the vicinity and directed to investigate. He found the plaintiff walking quietly along the street on his way home from a public entertainment; the hour was 11 p.m. Defendant, in uniform and known by plaintiff to be an officer, accosted plaintiff asking where he was going and where he lived. Plaintiff gave the requested information, but, in turn, questioned the officer's right to make the inquiries. The officer then asked plaintiff to give his name, which he refused to do. The officer further suggested that he walk with plaintiff to his residence; plaintiff declined, saying he could go home alone. Plaintiff's version of the ensuing conversation was as follows:

22 CAI. PEN. CODE $\$ 835$.

23 The discussion is confined solely to situations where the person being questioned is merely detained on the street rather than those where he is detained at a police station or jail. This must always be made explicit in considering police statements on the subject, since, in general, the police do not think of street questioning as "detention," even if it is accounplished by some form of reasonably genteel intimidation. In fact, they are quite surprised to find anyone curious about it.

24 See note 18 supra.

25 Thus, the lofficer might say, "You wouldn't want me to run you in for withholding information from the police, would you?" For a similar situation, see text at note 28 infra.

26 Often "vagrancy." See note 5 supra. If the person questioned happens to be driving, some deficiency in registration or alleged traffic violation may be more convenient.

279 Cal. App. 13, 98 Pac. 43 (1908). Many departments are probably vaguely familiar with the case since it is quoted at length in a mimeographed manual on the law of arrest used at the Seventh Annual Califormia Technical Institute of Peace Officers' Training in 1948, though it is cited to illustrate what constitutes "reasonable cause" at night, under CAL. PEN. CoDE $\S 836(5)$; 
Officer: Why are you hanging around here? What is your business anyway?

Plaintiff: I don't know if you got a right to question me that way for walking on the street-for walking houne.

Officer: If you don't want to answer, I will take you down to the station.

Plaintiff: All right; just go down there. I like to find out down there if you got a right to talk to me this way.

Officer: Don't you want to answer me any more?

Plaintiff: No; let's go down to the station. ${ }^{28}$

On the way to the station, the officer searched plaintiff for concealed weapons. ${ }^{20}$ Upon arrival at the station, the officer turned plaintiff over to the desk sergeant, saying: "Here is a man I took on Sunset Boulevard; he refuses to answer me."

In disposing of the civil action for false arrest, the court said:

A police officer has a right to make inquiry in a proper manner of anyone upon the public streets at a late hour as to his identity and the occasion of his presence, if the surroundings are such as to indicate to a reasonable man that the public safety demands such identification. ${ }^{30}$

To this statement of the officer's right, the court added a statement that the citizen's duty when called upon is to give all information in his power to the proper officers of the law as to persons connected with crime, ${ }^{31}$ and "this should be held to require that all proper information be given upon request of a personal nature, as affecting the one of whom inquiry is made, when the circumstances are such as to warrant an officer in making inquiry." 32

But where is the sanction by which this power and duty are to be enforced? To be sure, the court concluded that the officer did not unlawfully deprive the plaintiff of his liberty, and acted strictly in accordance with his lawful authority. However, since the court had already held that there was no arrest at all because the plaintiff had gone to the station "voluntarily," it cannot confidently be said that an arrest based on plaintiff's refusal to answer questions would have been approved. ${ }^{33}$

The supreme court denied a petition for a hearing, and further uncertainty as to the strength of the case persists because it has never since been cited in support of the right to detain and question, it gives no sanction by which to enforce such right, and it is peculiar in its facts-the "voluntary" nature of plaintiff's trip to the station.

A precise statutory provision giving the right to detain for questioning might clarify police techmiques in this type of situation, with benefit to the

289 Cal. App. at 15, 98 Pac. at 44.

20 See text at note 78 infra.

$309 \mathrm{Cal}$. App. at 16-17, $98 \mathrm{Pac}$. at 45.

31 Citing Miller v. Fano, 134 Cal. 103, 66 Pac. 183 (1901).

329 Cal. App. at 16, 98 Pac. at 44-45.

33 Nor does the department mentioning the case imply such a holding: " . . if the subject fails or refuses to answer questions propounded by the investigating officer, no specific charge can be placed against him." 
peace of mind of both officers and citizens. ${ }^{34}$ Most California police departments and officials questioned approved the idea of such a provision..$^{36} \mathrm{It}$ is one of the important proposals contained in the Uniform Arrest Act; ${ }^{30}$ and, in explicating the Act, Professor Warner points out that the provision would not be a completely untested novelty, since there was some allowance for detaining to question at common law. ${ }^{37}$ Furthermore, it is provided by statute in Massachusetts, ${ }^{38}$ may be inferred from the language of arrest statutes in some other states, ${ }^{39}$ and is authorized, in the absence of statute, by a 1937 Illinois case. ${ }^{40}$

\section{Requiring Witnesses to Give Information}

Sonewhat similar in its purpose to the provision giving police a statutory right to detain and question suspects is an optional section of the Uniform Arrest Act which makes it a punishable offense for a person reasonably believed to have witnessed a crime to refuse to give an officer his name and address, and offer identification, if requested. ${ }^{41}$ The provision was made optional because some states ${ }^{42}$ reported they had no experience of witnesses refusing to identify themselves for police, while others considered such a provision would be one of the most useful in the Act to them. ${ }^{43}$ Dis-

34 For example, consider the Gisske $v$. Saunders situation. The officer tried to bluff; the suspect called his bluff. Legally the suspect was right, yet from a practical point of view it would have been absurd for the officer not to have questioned him under the circumstances. How much better if the officer could have felt assured that he had a right to question, and had been able to show the suspect the statutory provisions in print. It would always encourage cooperation to explain to the subject that a crine had been committed; but sometimes ground for questioning may appear without this fact. In other cases it might be disadvantageous to a successful apprehension to give this information to every person questioned.

35 However, one district attorney with long experience dealing with arrest problems thought it unnecessary. His position was that almost all such questionings occur at night, and that a refusal to be detained or answer questions, when taken together with other circumstances, would almost invariably add up to reasonable cause for believing the subject had committed a felony.

36 Section 2. Questioning and Detaining Suspects.

"(1) A peace officer may stop any person abroad who he has reasonable ground to suspect is committing, has committed or is about to commit a crime, and may demand of him his name, address, business abroad and whither he is going.

"(2) Any person so questioned who fails to identify himself or explain his actions to the satisfaction of the officer may be detained and further questioned and investigated.

"(3) The total period of detention provided for by this section shall not exceed two hours. Such detention is not an arrest and shall not be recorded as an arrest in any official record. At the end of the detention the person so detained shall be released or be arrested and charged with a crime." Warner, supra note 11 , at 344.

372 Hade, Pleas of tee Crown 96, 97 (1st Amer. ed. 1847) ; 2 Hawkins, Pleas of the Crown c. $12, \S 20$, c. $13 \S \S 5-6$ (6th ed. I787); 4 Br. Conar. *292.

38 Mass. Gen. Laws C. 41, § 98 (1932).

39 E.g., Rev. Laws of N. H. c. $422, \S 13$ (1942).

40 People v. Henneman, 367 Ill. 15l, 10 N. E. 2 d 649 (1937), 37 Mich. L. Rev. 311 (1938).

41 This sort of requirement seems less objectionable than that peace-time registration cards, similar to World War II classification cards, be carried by every citizen, as proposed in Miller, Arrest Without Warrant by a Peace Officer in New York, 21 N. Y. U. L. Q. Rev. 61, 90 (1946).

42 Specifically, New Hampshire and Rhode Island, both of which adopted the Uniform Arrest Act in 1941, with very few other changes. See Rev. Laws of N.H. c. 423, \$§ 20-32 (1942), R. I. Acts AND Resorves, c. 982 (1941).

43 Because of the unwillingness of witnesses to give their names out of fear of gangster vengeance, unsavory publicity, or mere inconvenience. A loeal district attorney's office fecls that the provision would be of greatest value in the case of automobile accidents being investigated 
agreement on different grounds appears in the responses of two California departments to a broadly-worded query as to whether witnesses "withholding information from the police" should be inade a pumshable offense. "If the rights of society are paramount and the duty of the police is to protect society agamst the individual, it would appear that each individual should have the legal responsibility to assist the police in every way," writes one chief of police. The department in another city replied that, in addition to being too indefinite and impractical to enforce, such provision "would have the effect of making every citizen an informer under pain of becoming a criminal himself."

Since it was understood that answers to the questionnaire would represent only cursory judgments, it is not unlikely that, upon further consideration, the former official would grant the impractical nature of a too-broadlydefined offense and the latter would grant the usefulness of one confined to requiring that name, address, and identification be given by witnesses. ${ }^{44}$

\section{Refusing to Arrest on Citizen's Charges}

It is a serious offense for any peace-officer wilfully to refuse to receive or arrest any person charged with a criminal offense. ${ }^{45}$ Although the pertinent statute has been construed by the courts only in situations involving the duty of jailers to receive prisoners from other persons, its clear meaning would seem to be that a police officer may not refuse to take into custody a person charged by a private citizen with any "criminal offense."

Almost invariably the situations which come under this stricture are domestic quarrels which have reached the point of violence. Called to quiet the disturbance, an officer is frequently directed by one of the parties to the altercation to arrest the other for assault and battery. Familiar with the fact that charges which arise in such circumstances are seldom pressed to a conclusion, the officer can (1) take the accused into custody, representing a considerable expenditure of time, use of patrol wagon and jail space, and so forth, for a rather trivial purpose; (2) he can attempt to dissuade the accuser from requiring that the other party be jailed, with considerable consequent waste of time, regardless of his success; or (3) he can break the law, at least technically, by refusing to take the accused into custody and directing the accuser to come to the station the following day to lodge charges. The average police officer does not think these alternatives completely satisfactory. He believes that he should have some legal discretion,

for possible felony violations, and adds that there should be a penalty for giving false names under such circumstances.

44 With respect to more serious withholding of information, the latter department considers the problem is adequately covered by CAx. Pen. ConE $\$ 32$ : Every person who, after a felony has been committed, harbors, conceals or aids a principal in such felony, with the intent that said principal may avoid or escape from arrest, trial, conviction or punishment, having knowledge that said principal has committed such felony or has been charged with such felony or convicted thereof, is an accessory to such felony. Query whether the requirements that witness have knowledge of commission by principal and intend to aid principal do not limit the usefulness of the section.

45 Cax. Pen. Code \$ 142. 
rather than being obliged to break the law, at his own peril, whenever he thinks he should refuse to arrest.

If an officer's duty to accept prisoners is to be made discretionary, some safeguard to provide a ground for subsequent review of his.action must be established, some "reasonable cause" to believe the charge is frivolous and will be abandoned. Such element would be more difficult to define in terms of what a "reasonably prudent man" would believe than is "reasonable cause" for suspicion or belief in guilt, since it is actually based to a much greater extent on what a "reasonably prudent and experienced officer" has reason to believe.

Perhaps the answer lies in the proposal for the extended use of citations for minor offenses. ${ }^{46}$ If a police officer were required to arrest or issue $a$ citation to any person charged with a criminal offense, but if, for certain offenses it were to be in his discretion which course of action he would follow, it would be possible for him to deal quickly, lawfully, and quite adequately with these situations.

\section{Felony-Misdemeanor Problems}

Professor Jerome Hall, though proffering counsel of caution with respect to most statutory change, has stated flatly:

... [I]t is clear that we should abolish the archaic classification of felony and misdemeanor and with it the fiction which, among other absurdities, requires a policeman to determine on the spot and under exciting conditions, questions upon which supreme court judges differ after considerable deliberation. ${ }^{47}$

At this point, the police themselves rise to counsel caution. One department, admitting that arrests without warrants are occasionally made for misdemeanors not committed in an officer's presence "when there is substantial evidence to warrant a prosecution," 48 approves a proposal that rules permitting arrest without warrant ${ }^{40}$ be made identical for felonies and misdemeanors only in the case of selected inisdemeanors, such as drunk driving, vice violations, and shop-lifting. ${ }^{50}$ It is further urged that the selection of misdemeanors to be so handled would require careful study and consultation.

If the purpose of revision is to simplify the problems faced by an arresting officer in a situation of urgency and confusion, making different rules for separate categories within the misdemeanor classification would be a backward step; but if the intention is to make possible the apprehension

46 See text at note 72 infra.

47 Hall, Law of Arrest in Relation to Contemporary Social Problems, 3 U. of CHI. L. REv. 345,374 (1936).

48 "Unless the rule is modified by statute, an officer cannot arrest without a warrant for a misdemeanor not committed in his presence and view ...." Pcople v. Perry, 79 Cal. App. 2d Supp. 906, 180 P.2d 465, 467 (1947); see Ware v. Dunn, 80 Cal. App. 2d 936, 183 P. 2 d 128 (1947) ; Hanna v. Raphael Weill \& Co., 90 Cal. App. 2d 461, 203 P. 2 d 564 (1949).

49 Cat. Pen. Code \& 836.

50 Most such offenses may be either misdemeanors or felonies depending on the value of property stolen, the results following from commission of the offense or the punishment imposed. 
of certain types of offenders who are at present unduly protected by the concurrence of Penal Code Section 836(1) with the distinction between felonies and misdemeanors, the proposal has merit.

On the other hand, another California department flatly rejects the proposal to make the rules governing arrest without warrant uniform for felonies and misdenieanors. It is asserted that officers of that department follow the provisions of Penal Code Section 836(1), presumably impeccably. ${ }^{51}$ This departnent disapproves wiping out the felony-misdemeanor distimction with particular vehemence where the use of deadly force niay be involved in the course of the apprehension. The point is well taken. The statutes concerning the permissible use of force in arrest-and, in particular, deadly force-are vague and call for clarification in any event, ${ }^{52}$ but it is generally held that a lesser degree of force is justifiable in effecting an arrest for a misdemeanor than for a felony.

The Uniform Arrest Act does not abolish completely the felony-nisdemeanor distinction. Leaving the details of just what the distinction is to be filled in according to local taste, ${ }^{53}$ the Act stipulates that:

(1) An arrest by a peace officer without a warrant for a misdemeanor is lawful whenever:

(a) He has reasonable ground to believe that the person to be arrested has committed a misdemeanor in his presence.

(b) He has reasonable ground to believe that the person to be arrested has committed a misdemeanor out of his presence, either within the state or without the state, if law enforcement officers of the state where the misdemeanor was committed so request, and will not be apprehended unless immediately arrested..$^{54}$

(2) An arrest by a peace officer without a warrant for a felony, whether committed within or without the state, is lawful whenever:

(a) He has reasonable ground to believe that the person to be arrested had committed a felony, whether or not a felony has in fact been committed.

(b) A felony has been committed by the person to be arrested although before making the arrest the officer had no reasonable ground to believe that the person committed it..55

With respect to permissible force, the Act implicitly preserves a distinction between the force which nlay be used in effecting arrests for misdemeanors and felonies. It makes allowance for the officer's difficulty in making the distinction "off the cuff" by justifying force commensurate with a felony arrest where the officer has reasonable ground to believe the person to be arrested has committed a felony. ${ }^{56}$

E1 Except that their officers occasionally arrest without possession of a warrant when the warrant is in the possession of the department's warrant bureau. See text at note 95 infra.

62 See text at note 81 infra.

53 CAL. PEN. CoDe $\$ 17$.

ت1 It was probably the draftsman's intention that the clause "if law enforcement officers of the state where the misdemeanor was committed so request" apply only to misdemeanors occurring outside the state.

55 UNIFORM ARREST ACT $\$ 6$. Warner, supra note 11, at 345 .

56 UNIFORAI ARREST ACT $\$ 4$. Warner, supra note 11, at 344-345. 
It is probably desirable to preserve the prohibition against the use of deadly force in the case of minor offenses. ${ }^{57}$ It is difficult to see, then, how the felony-misdemeanor distinction can be abolished without supplanting it with some other distinction, equally troublesome for a harassed policeman to apply - or perhaps even the sarne distinction in another guise..$^{68}$ Probably some useful changes could be made if, instead of imposing a blanket abolition, separate consideration would be given to how the distinction impinges on (1) problems of when an arrest may be made without a warrant, and (2) when an officer is justified in using deadly force to effect an arrest.

According to Professor Warner's interpretation, the felony provisions of the Uniform Arrest Act, which concern arrest without warrant contain only one slight extension of power to arrest beyond those enumerated in the pertinent portions of Penal Code Section 836. Under that section, though no felony has in fact been committed, an arrest is lawful if based on an apparently reliable complaint by day or on any reasonable ground by night. The effect of the Uniform provision would be to make any reasonable ground sufficient justification by day or by might.

However, it may come as a surprise to many lawyers to learn that Professor Warner would not consider the provision making a felony arrest without warrant lawful where the party arrested has in fact committed a felony even though the officer had no reasonable ground for believing in the arrested person's guilt to be an extension of California law. In arguing the case for his own provision, he asserts that it is already in force in fifteen states, as well as being embodied in the American Law Institute's Code of Criminal Procedure. One of these fifteen states is said to be California. The provision referred to is Penal Code Section 836(2), providing that a peace-officer may arrest without a warrant "when a person has committed a felony, although not in his presence." Professor Warner contends that "reasonable ground" is not properly read into the section-that its omission from this section, as opposed to the three sections that follow, must be considered to be deliberate and meaningful. Although this interpretation may be the proper one, the courts of California have not made it explicit in the ouly two cases which cite this subsection ${ }^{50}$ and the attorney general of the state, paraphrasing the provision slightly in the course of a 1950 opinion $^{60}$ has left the issue very much unresolved.

57 Professor J. B. Waite believes that the right of the police to use force dangerous to human life should not depend on the crime committed, but should be dependent upon three limitations: (1) that the force is apparently necessary, (2) that the arrest is lawful, and (3) that the officer has reasonable ground to believe that the person to be arrested is aware that an arrest by a police officer is being attempted and could avoid injury by submission. Waite, Some Inadequacies in the Law of Arrest, 29 MrCH. I. REv. 448, 467, n. 42 (1931).

58 It is significant that Professor Hall buttresses his contention that the felony-misdemeanor distinction should be abolished with quotations from British police authorities. Though many British police techniques are changing, British policemen were not customarily armed at the time Hall was writing, so that the use of deadly force did not present the same problem as in this country.

59 People v. Pool, 27 Cal. 572 (1865); People v. Dallen, 21 Cal. App. 770, 132 Pac. 1064 (1913).

6015 Ops. Cal. Atty. Gen. 291, 295 (1950). 
Professor Warner cites three cases which give only slight color to the construction argued for. ${ }^{61} \mathrm{He}$ appears to have overlooked Missouri, where it has been stated firmly that scienter on the part of an officer is not necessary to make an arrest lawful when it is discovered that the person arrested did in fact commit a felony. ${ }^{62}$

Of course, the lack of general judicial support for what Professor Warner proposes does not necessarily prove its unsoundness. The main reasons he advances in support of his suggested provision are: (1) that it would permit the introduction in evidence of guns or other contraband articles found on the arrested person, even though there was no "reasonable ground" to believe in defendant's guilt at the time of the arrest, ${ }^{63}$ and (2) that although it is often difficult to prove that the officer acted reasonably, he usually has done so. ${ }^{64}$ Some others who have considered the problem support the proposed rule. ${ }^{65}$

\section{Extended Use of Summons and Citations}

Proposals to extend the use of summons or citations to supplant formal arrest for minor offenses are not called forth by abusive or illegal practices on the part of the police, nor need they be considered in the light of court decisions. In some jurisdictions, it is considered that the use of citations in traffic offenses grew up without legislative foundation; ${ }^{66}$ but in this state the Vehicle Code makes explicit provision for their use; ${ }^{6 r}$ in fact, such provision has been made simce the first rules concerning automobiles were adopted in $1915^{\text {BS }}$

In England a justice may, if he thinks fit, issue a summons instead of a warrant for arrest for the commission of any offense, even a felony, if he is

61 Cline v. United States, 9 F. 2d 621 (9th Cir. 1925) quotes a statute which omits "reasonable cause," without construing it; however, the case was later cited in Foster v. United States, 11 F. 2d 100 (9tb Cir. 1926) in support of the proposition that a "reasonable ground" for belief will justify a felony arrest without warrant. See Johnson v. Bruckheimer, 133 App. Div. 649, 118 N. Y. Supp. 189 (1909) in which a requirement of "reasonable cause" is imposed. In Hochderfer v. State, 50 Okla. Cr. 304, 297 Pac. 317 (1931), the facts suggest that the court did consider there was "reasonable cause"; there is no indication that the decision would have been the same had this element been lacking.

62 State v. Whitley, 183 S.W. 317, 320 (Mo.1916); see State v. Nolan, 354 Mo. 980, 192 S. W. 2d 1016 (1946); State v. Williams, 328 Mo. 627, 631, 14 S. W. 2d 434, 435, 436 (1929).

63 But this is unnecessary in California which already permits the introduction in evidence of articles obtained through illegal search. People v. Mayen, $188 \mathrm{Cal}$. 237, 205 Pac. 435 (1922) (illegal search of premises); People v. Watson, 57 Cal. App. 85, 206 Pac. 648 (1922) (applying rule to illegal search of person).

o-4 Reasons the police officer may not be able to establish this are that he cannot reveal that he acted on information from a rehable "stool-pigeon" without jeopardizing sources of information; or, quite probably, that he simply is not capable of putting into words which will convince a judge what he, as an experienced police officer "felt in his bones." Professor Wainer asserts that fear of departmental discipline and of suits for false arrest prevents unreasonable arrests.

65 Waite, Public Policy and the Arrest of Felons, 31 Micr. L. Rev. 749 (1933); Bruce and Rosmarin, The Gunman and His Gun, 24 J. CRTar. L. 521 (1934).

60 See Mormon v. Baran, 35 N. Y.S.2d 906, 909 (1942).

67 CAL. VEH. CODE $\$ 739$.

68 CAL. VEH. ACI $\S 22$ (c), c. 188 (May 10, 1915). 
satisfied that the person summoned will appear. ${ }^{60}$ A minority of American states have statutes permitting or requiring the issuance by a magistrate of a summons instead of a warrant..$^{.0}$

However, since these statutes involve summons issued by a magistrate, they are only substitutes for arrests under warrant rather than for arrests without warrant. The heart of proposals for extending the use of "summons" is the extension of its issuance by officers. Although in general usage the two terms are apt to be confused and used interchangeably, it will be found useful to distinguish the former as "summons" and the latter as "citation."

Apparently most California police departments would welcome an extended use of citations, similar to traffic "tickets" in cases of minor offenses. One department says it would be "beneficial." Another approves the proposal, providing that the defendant can provide evidence of identity and responsibility to answer to the charge. These safeguards might be made explicit in any statute adopted, or they might be made implicitly by framing the statute in permissive rather than mandatory terms. ${ }^{71}$

The main argument in favor of an extended use of both summons and citation is that the person who commits certain minor misdemeanors is not a "criminal" in any real or serious sense. Anything like a formal arrest, involving his being led away by the arresting officer, not only does him an injustice but also is likely to confuse the attitude of the public toward those who commit more serious crimes. A citizen who feels a sense of injustice when he sees a brawling baseball fan headed for the police wagon may transfer his sympathy to anyone he sees being led away by a policeman, even when the culprit may be guilty of some thoroughly vicious conduct.

In support of an extended right of officers to issue citations without application to a magistrate, it may be added: (1) that the practice would save officers a great deal of timie and trouble over relatively minor incidents; (2) that it may avoid undue hardship on innocent persons, as where the arrest of an unlicensed peddler might leave his accompanying child unable to get home; (3) that it would avoid the tendency of officers to leave minor offenders completely without punishment where arrest seems too severe and application for a summons or warrant too troublesome; and (4) that it is desigued to further personal liberty rather than to restrict it.

Against such a system it may be urged that the use of "tickets" in traffic violations has a tendency to engender cynicism toward the law, because the average citizen's inclination is to pay the penalty for non-appearance rather than attempting to defend, even where he believes himself to be innocent. However, the cynicism which might occasionally result from an extended use of citations seems hardly more serious than that which arises

$6911 \& 12$ VICr., c. $42, \S 1$.

70 E.g., for intoxication and blasphemy, PA. STATs., Title 18, $§ 632$ (Purdon, 1936); discretionary for inisdemeanors punishable by imprisonment, mandatory for all other misden meanors and lesser offenses, W. VA. CoDE, c. 62, Art. 2, 113 (1949); for offenses punishable by fine only or by imprisonment for not more than one year, with or without fine, and offenses by children under 14, MAss. GEN. LAws, c. 276, § 24 and c. 119, \$ 54 (1942).

71 Section 9 of the UNIFORM ARREST ACT is so phrased. Warner, supra note 11, at 346. 
in both officer and citizen when the former decides not to bother applying to a magistrate but rather to let an offender go unpunished, or the resentment engendered by a formal arrest for a minor offense. ${ }^{72}$

\section{Right to Search for Deadly Weapons}

Reference has already been made to the fact that police officers conduct many more questionings than arrests. ${ }^{\text {T3 }}$ In addition to the methods used to convince suspects that they should submit to questioning, insistent, though relatively courteous and inoffensive, techniques of "frisking" suspects are part of every officer's stock in trade-the balance between insistence and courtesy varying from department to department and officer to officer. Hale, Hawkins, and Blackstone never saw a four-inch automatic pistol, but to officers who have it does not seem unreasonable to search a person being questioned who may be armed. ${ }^{74}$

Yet, according to the general rule ${ }^{75}$ and the clear wording of the pertinent California statute, ${ }^{76}$ a search of the person is lawful only when making a formal arrest. Where officers question nimety-five persons to every one arrested, three alternatives are open: (1) arrest every person they fear may be armed on some nominal charge, in order to legalize an immediate search; (2) take a great many chances on sudden treachery; (3) perpetrate a number of technically illegal "frisks." It is not surprising that officers usually adopt the last-mentioned course of action.

It is difficult to flnd a court stating flatly that such searches are illegal, but it is clearly implied by holding after holding that a search of the person is permissible when incidental to a lawful arrest. The court in a Califorma case, Gisske v. Saunders, which stands almost alone in the country, goes beyond this to approve a search where there was no arrest, stating:

... the officer did nothing which the plaintiff did not desire, except the examination of his person to. see if he carried concealed weapons. This, however, was a precaution which the officer might well take under the circumstances of the meeting and the conduct of the plaintiff, whether plaintiff was under arrest or not. ${ }^{\text {Th }}$

This 1908 case is presumably law in California, smce it has never been overruled. Neither, however, has it been since approved. And not even the police department which made the most careful response to the questionnaire indicated that it considered its practice to be legal on this basis. How-

72 At least one California district attorney's office uses an infornal "citation" technique in dealing with consplaints by citizens. Rather than issuing a warrant on a citizen's charges, a request to appear is mailed to the person charged, and only upon his failure to comply is a warrant issued. This technique is particularly useful in cases of alleged "failure to provide."

73 See note 18 supra.

74 "Not even the most ardent defender of civil liberties looks upon every search without warrant as a violation of the letter or the spirit of the Constitution. Search and seizure is oppressive only when unreasonable." Harry M. Fisher, Judge of Circuit Court of Cook County, in Introduction to Baker, Manual of ArRest, SEARCH and Seizure (Chicago Crime Commission, 1944).

756 C. J.S. 620.

76 Car. Pen. Code $\$ 846$.

77. 9 Cal. App. at 16, 98 Pac. at 44. 
ever, another department stated: "It is believed that there is a Supreme Court decision upholding officer's right to take such action." (Emphasis added.) All questioned agreed they would like to see a provision allowing "frisking" clearly enunciated in statutory form.

As Professor Warner points out, the enactment of a statute legalizing these searches would probably have little effect on police practices. ${ }^{i 8}$ Police officers will contimue to be governed by the instimct for self-preservation and will "frisk" suspects, regardless of the legality of their act. The only possible difference in result might be that suspects arrested on a nominal charge, merely im an attempt by the officer to legalize his search, would not be subjected to such inconvenience. ${ }^{79}$ However, the real benefit would be in reducing the number of situations in which the police officer is forced to feel that the law is not responsive to what his acute interest in staying alive tells him is essential. ${ }^{80}$

\section{Permissible Force}

The question of the amount of force appropriate to any given arrest situation is not one that can be wrapped up in precise statutory language and delivered with an air of finality. Nevertheless, the department already referred to as having given the most thorough and thoughtful response to the questionnaire is vigorous in its contention that the question of permissible force needs revision, clarification, and a greater degree of explicitness.

The only statute dealing specifically with the force permissible in effecting an original arrest (as opposed to recapture) is Penal Code Section $843 .^{81}$ In addition to being vague, particularly with respect to deadly force, the statute applies only to arrest under a warrant. Since the proportion of arrests not under warrant is estimated by representative police departments at between $75 \%$ and $90 \%$, it is clear that most arrest situations are not covered by this provision. Courts have had little difficulty in assuming that the rule of permitting "force which, from the surrounding circuinstances, seems to him, as a reasonable man, necessary" $" 82$ applies to any arrest, regardless of whether or not it is under the authority of a warrant. Penal Code Section 854 , on pursuit and recapture, ${ }^{83}$ although it draws no needless distinctions as to whether the arrest was with or without warrant, offers no

78 Warner, The Uniform Arrest Act, 28 VA. L. Rev. 315 at 325.

79 An apparently insoluble difficulty in this sort of provision is that it would be used to justify illegal searches for stolen goods and other contraband. If a question is raised as to the legality of these searches, it would be almost impossible to disprove an allegation by the officer that he was really searching for dangerous weapons.

80 This is the major justification for most of the proposals to "regularize" existing police practices which go beyond statutory limits. If the officer believed that there were fewer such deficiencies in the law, he would have greater respect for it and would be less likely to transgress in more objectionable ways.

81. "When the arrest is being made by an officer under the authority of a warrant, after information of the intention to make the arrest, if the person to be arrested either flees or forcibly resists, the officer may use ail necessary means to effect the arrest."

82 People v. Adams, 85 Cal. 231, 24 Pac. 629 (1890).

83 "If a person arrested escape or is rescued, the person from whose custody he escaped or was rescued, may immediately pursue and retake him at any time and in any place within the state." 
guidance as to permissible force, especially deadly force. Apparently, the only situations in which an officer is justified in using deadly force are those in which resultant homicide would be justifiable. ${ }^{s t}$

The police department mentioned above raises the following questions:

May a police officer use deadly force in arresting a subject who has committed a felony which itself does not involve any force or violence-as, for example, forgery? ? $^{85}$

May a police officer, under the provisions of Penal Code section 4532, 86 making escape attempts a felony, use deadly force in attempting to recapture a prisoner in his custody whom he has originally arrested for a misdemeanor? 87

How broad is the power to use deadly force implied in Penal Code section 197 (4): "Homicide ... is justifiable ... when necessarily committed ... in lawfully suppressing any riot, or in lawfully keeping and preserving the peace"?

Does "necessary" in the various statutes mean "necessary to effect the arrest" or "necessary to save the officer from death or serious injury"?

These are among the questions which have not been considered by the California courts, or concerning which there appear to be conflicting rules. Their seriousness makes clarifying legislation desirable before it becomes necessary to test them in court.

\section{Taking Away Right to Resist Illegal Arrest}

"The right of a person to resist unlawful arrest cannot be denied." Thus spoke the supreme court in 1907. Forty years later, an appellate department of a superior court was still dutifully re-affirming the proposition: "If an arrest is unlawful, either the person arrested or others acting in his behalf may resist the arrest. ${ }^{239}$ The principle seems to be universal and virtually unchallenged by statute or court decision. ${ }^{90}$ Not so where writers ${ }^{91}$ and police departments are concerned. The latter are unanimous in believing that physical resistance to an arrest by an officer whose identity is known to the suspect should be forbidden. This does not mean that they believe police should not be subject to restraints against illegal arrests, but they do believe that the proper forum for determining the lawfulness of an arrest should be the courts, not the scene of the arrest. This means civil or criminal redress in actions for false arrest must be effective to vindicate the rights of

\footnotetext{
84 Cal. Pen. Code $\$ \S 196,197$.

85 See People v. Dallen, 21 Cal. App. 770, 132 Pac. 1064 (1913).

88 "Every person charged with or convicted of a felony or misdemeanor . . . who escapes or attempts to escape ... from the custody of any officer or person in whose lawful custody he is, is guilty of a felony ...."

87 But cf. People v. Lathrop, 49 Cal. App. 63, 192 Pac. 722 (1920); People v. Melendrez, 129 Cal. 549, 62 Pac. 109 (1900).

88 People v. Craig, 152 Cal. 42, 91 Pac. 997 (1907).

89 People v. Perry, 79 Cal. App. 2d Supp. 906, 180 P. 2d 465, 470 (1947).

s0 Voorhees, The Law of ARRest 77 (2d ed. 1915); see CorneluUs, The Law of Search aNd SEIZURE 180, n.38 (2d ed. 1930) for annotation.

01 Miller, Arrest Without a Warrant by a Peace Officer in New York, 21 N.Y.U.L.Q. REv. 61, 89 (1946).
} 
a wrongfully arrested citizen. ${ }^{92}$ The fact is, as Professor Warner points out, that the law-abiding citizen will almost invariably rely on such redress in any event. The innocent arrestee is not apt to risk committing an offense and inviting retaliatory force by physically resisting an officer. Unarmed and unaccustomed to opposing the police, the idea of escape does not occur to him. It is the guilty person, particularly the habitual offender, who will offer resistance to an arrest, be it legal or illegal. It is only after the arrest, when the offender's lawyer enters the picture, that the legality of the arrest is considered; and, if some technical flaw can be discovered, the resistance which was prompted not by innocence but by guilt will be exculpated.

The right to resist illegal arrest developed in England, during a period when long imprisonment was common, bail for felonies was usually unattainable, and death from disease was as apt to deliver a prisoner as the royal judges whose arrival for a jail delivery might take years. ${ }^{23}$

As times change, problems change, and as problems change, solutions should change. Whatever their deficiencies, California's jails are not medieval. On the other hand, physical resistance to the swords or staves of 18th century constables and watchmen did not hold the serious menace which results to officer, suspect, and innocent bystanders from flying bullets.

Whether or not to impose a penalty for physical resistance to arrest by a known officer is another question. Section 6 of the Uniform Arrest Act does not do so. Its authors considered it sufficient to make such act illegal, thereby preventing a person who kills or wounds an officer from defending homicide or assault charges by contending the arrest was illeggll.

\section{Arresting Without Possession of Issued Warrant}

One of the least controversial changes proposed would be to make specific statutory provision that a warrant need not be in the possession of the officer arresting under its authority, if it is in the possession of the police department to which the officer is attached, or has been communicated to that department by official teletype from another department in the state.

Penal Code Section 842, requiring that the warrant be shown to the person arrested "if required," does not specify that this must be done immediately. Section 836, however, provides that an officer "may make an arrest in obedience to a warrant delivered to him." (Emphasis added.) Although this inight conceivably be construed to mean delivered either before or after the arrest, it is more likely to be interpreted as meaning before, and the requirement is not avoided by the section authorizing an officer to arrest if in possession of a telegraphic copy of the warrant, ${ }^{94}$ since teletype and radio have become so dominant in police operations. Characteristically, information is received through the statewide teletype network, and a direction to arrest goes out to large numbers of police officers by bulletin and

02 See text at note 120 infra.

03 Howard, The State of the Prisons in England and Wales $\$ 1$ (Eyres 1780); Gentleman's Magazine, January, 1759, as reported in WebB, ENglish Prisons UNDER Local GuvernMENT 21 (1922).

94 Cal. Pen. Code $\S 850$. 
radio. Surely it would sufficiently answer the original intent of the statutes that the person arrested be informed by the arresting officer upon demand of the nature of the charge and be shown the warrant or its teletyped substance upon arrival at the police station. This is, in fact, the practice of most police departments, as those questioned were prompt to admit. ${ }^{95}$

\section{Delay in Bringing Prisoner Before Magistrate}

Penal Code Section 849 says there must be no "unnecessary delay" in taking an arrested person before a magistrate, when an arrest has been made without a warrant. ${ }^{96}$ This section was adopted in 1872 , and has since been subject to only one very minor amendment. On the other hand, under the chapter entitled "The Warrant of Arrest" appears Section 825, which originally stated the same requirement, but to which in 1880,97 and in $1907,{ }^{98}$ was added a detailed statement of the prisoner's right to see an attorney. In its present form the provision seems to be predominantly concerned with that subject. But the "unnecessary delay" interdiction remained, and in 1927 the legislature added "and, in any event, within two days after his arrest, excluding Sundays and holidays."

In the case of Williams v. Zelzah Warehouse Co., ${ }^{100}$ decided five years later, an arrest was made without a warrant. The court invoked Sections 849 and $145,{ }^{101}$ but made no mention of the impact of the "two day" clause in Section 825 as possibly modifying the "unnecessary delay" of Section 849. The detention involved was for 33 hours, which the court declared clearly unnecessary, citing cases decided prior to the amendment of Section 825 which had held periods as short as one and a half and four hours to be unnecessary delay within the meaning of Section $849 .^{102}$

Following this case came Peckham v. Warner Bros., ${ }^{103}$ in which two plaintiffs alleged false arrest based on delays of 24 and 48 hours. The court held that the question of whether these periods constituted an "unreasonable delay" was properly submitted to the jury. The court cited Section 849 and

95 However, the change may be redundant if the theory relied on in at least one metropolitan department is accepted. It is there contended that when an officer has received information of the existence of a warrant through official channels, lie has "reasonable cause" sufficient to arrest without a warrant.

96 CAT. PEN. CoDE $\$$ 849: "When an arrest is made without a warrant by a peace-oficer or private person, the person arrested must, without unnecessary delay, be taken before the nearest or inost accessible magistrate in the county in which the arrest is made, and a complaint stating the charge against the person, must be laid before sucl magistrate."

97 Cal. Stats. 1880, p. 30.

98 Cal. Stats. 1907, p. 888.

09 Cal. Stats. 1927, p. 1044.

100126 Cal. App. 28, 14 P. 2 d 177 (1932).

101 CAI. PEN. CoDE $\$ 145$ : "Every public officer or other person, having arrested any person upon a criminal charge, who willfully delays to take such person before a magistrate liaving jurisdiction, to take his examination, is guilty of a misdemeanor."

102 Vernon v. Plumas Lumber Co., 71 Cal. App. 112, 234 Pac. 869 (1925) ; Gomez v. Scanlan, 155 Cal. 528, 102 Pac. 12 (1909). If it had chosen to, the court could have disposed of Section 825 , by holding the delay unnecessary because there was no evidence of any effort to collect evidence during the period of detention or otherwise justify the delay, and magistrates , with appropriate jurisdiction were readily available.

10336 Cal. App. 2d 214, 97 P. 2 d 472 (1939). 
quoted at length from the pre-amendment case of Vernon v. Plumas Lumber Co., ${ }^{103 a}$ but failed to mention Section 825 .

Apparently the first judicial notice of the 1927 amendment came seventeen years after its adoption in People v. Zammora, ${ }^{104}$ where it was stated that Section 825 defines the "unnecessary delay" of Section 849 as meaning "in any event, within two days after his arrest, excluding Sundays and holidays. "Two days was said to be the time "allowed" to bring a prisoner before a magistrate under both sections. This was dictum since appellants' detention for a week was held clearly longer than necessary.

Two recent cases decided in district courts, involving arrests without warrant, leave the issue uncertain. In People v. Sewell, the court said:

It appears from the record that he [defendant] was booked at the city jail on the afternoon of January 18th [1949, a Tuesday] on a charge of drunkenness and on suspicion of robbery, and on the morning of the 20th, within the two days maximum time set forth by Penal Code section 825, he was brought into court and pleaded guilty to drunkenness. ${ }^{105}$ (Emphasis added.)

Since they had not exceeded the two days maximum, the police were not required to show that two days detention was necessary or reasonable.

Yet im Hughes v. Oreb, ${ }^{106}$ decided six months later, another district court held that being imprisoned incommunicado for 33 hours with no charge was unreasonable and unwarranted delay which constituted false imprisonment, citing the Williams line of cases. Concluding that the plaintiff's allegations placed the burden on the officers to establish the legality of the detention, the court reversed directed verdicts for the defendant officers. No inention was made of Section $825^{10}$ These two cases may not be totally irreconcilable. Nevertheless, because they fail to take cognizance of each other, there is uncertainty as to whether or how forcefully the qualification of Section 825 applies to "unnecessary delay" in producing a person arrested without a warrant before a magistrate.

By questionnaire, California police departments were asked: "Should specific statutory provision be made permitting 24 hours delay in bringing accused before a magistrate, plus 48 more hours upon showing good cause before a judge?" Surprisingly, none of the three police departments answering inentioned Section 825 or such cases as People v. Sewell or People v. Zammora. One department said "Yes"; another said "Yes, provided accused has protection (civil redress) in cases of illegal or unjustified deten-

103a Supra note 102.

10466 Cal. App. 2d 166, 220, 224, 152 P. 2d 182, 208 (1944).

10595 Cal. App. 2d 850, 856, 214 P. 2d 113 (1950).

10699 A. C. A. 239, 245, 221 P. 2d 327 (1950).

${ }^{10}$ However, the reversal was alternatively placed on the ground that no reasonable cause for belief in plaintiff's guilt lad existed to justify the original arrest without warrant. Even if Section 825 had been considered, the detention might have been unreasonable because of the fact that it was incommunicado and that another suspect had confessed to the crime for which plaintiff was being held 24 hours before the latter was released. 
tion"; the third said "If such a statutory provision would constitute a denial of bail during said period, we believe it would be unreasonable."108

The departments were then asked whether they ever find it necessary to delay a prisoner's appearance before a magistrate to allow sufficient time for more evidence to be collected. One said "Very infrequently-probably not more than 5 or 6 times a year." Another, with a vastly greater number of arrests, said "... so infrequently as to make impracticable any estimate on a percentage basis." But this department stated further that "as a practical matter" a prisoner is not brought before a magistrate until the morning following his arrest, and: "This may involve a detention of another period of twenty-four hours at the request of the prosecution for a continuance." Presunably, such a request would require "showing cause," so the practice includes a safeguard. The third department stated quite bluntly: ". . . this is quite common; alnost daily." 109 One large district attorney's office strongly favors the 72-hour maximum, alleging that booking procedures and irreducible administrative procedures in both police department and district attorney's office, combined with unforeseeable delays in collecting evidence make this period essential.

The question posed to these departments was in terms of the solution which the Uniform Arrest Act makes for this problem. Since allowance for delaying appearance before a magistrate while gathering information has already been made by the legislature under Section 825 and has received at least occasional judicial recognition, it is not a totally unapproved innovation. Even if no further modification of the law on this point is desired, it would be well to alter Section 849 to conform to Section 825 , so that all provisions dealing with the same subject will be uniform and the judicial treatment may be consistent.

\section{Release by Police Without Charging}

If any "actual restraint of the person" of the defendant is an arrest, ${ }^{110}$ and if any person arrested must be brought before a magistrate without unnecessary delay, ${ }^{111}$ then for a police officer to release a prisoner without producing him before a magistrate is not lawful. ${ }^{112}$ Nevertheless, such releases are frequently inade where the offensè is drunkenness, and occasionally in the case of other offenses. The practice of officers on beat or patrol

108 When Los Angeles bookies worked out a "quickie writ" arrangement which resulted in the release of arrestees on bail immediately upon arrival at the station, local judges made an informal agreement not to sign the writs for 24 hours after the arrest, so that the police might question the arrestees. And in England under the "delayed charge," a station officer may deny bail if the crime or prisoner make that appropriate, provided that the prisoner comes before the Court session next beginning after his arrest and arrival at the station. See REPORT OF ROYAI Conanssion on Police Powers and Procedure 53-54 (1929).

109 Unfortunately, this gives no indication of how long such delays ordinarily run; the statement may actually signify no different procedure from that of the preceding department.

110 CAL. Pen. CODE $\$ 835$, and see note 23 supra.

111 Car. Pex. Code $\$ 849$, and see text at note 96 supra.

112 One California police department urges that "these provisions relate to the delay rather than the failure to bring the prisoner before a inagistrate." However, the department adds that "it is deemed inadvisable to release any prisoner without express authorization by a magistrate or other person clothed with some judicial power." 
detaining a person briefly and then permitting him to go without being taken to the station already has been discussed. ${ }^{113}$ Releasing on police authority after a person arrested has actually been taken to a police station, whether or not he has been booked is another problem.

One California department, which books drunks under a local ordinance rather than under vagrancy ${ }^{214}$ or intoxication provisions of the Penal Code, releases about fifty percent as soon as they sober up, without an appearance before a magistrate. ${ }^{115}$ These releases are subsequently "approved" by a municipal judge. The practice seems tolerable though discouraging. In a sense, it represents an attempt by the department to increase personal liberty rather than to limit it. Incarceration of drunks is not intended as a punishment; few if any of the classic goals of punishment are served by it. The removal of drunks from the street is a convenience to the general public, but it is also a considerable protection to the drunk himself from the possibilities of robbery, beatings, or injury from falling or being struck by an automobile. Once the prisoner is sober, no end is served by preserving his technical right to appear before a magistrate. In some cases, it may actually work a hardship on him, if for example he is not an habitual drunkard but a working man with a job to get to at an early hour the following morning, it is no service to him to be detained until court opens, in order that the charge against him may be dismissed by a judge rather than by a police sergeant.

Professor Hall, in 1936, ${ }^{116}$ attempted an elaborate analysis of admittedly incomplete statistics to find out how many releases are made by the police. The results were inconclusive, but he nevertheless viewed them with great alarm. There is cause for alarm, but it is not the technical illegality of the police action, but the dissipation of police energy. Hall complains that such "treatment" of drunks serves no purpose other than to facilitate re-arrest upon the same charge; in other words, it is not remedial. Despite the protective aspects there is validity in this contention, but it seems irrelevant to a consideration of police methods. If a community wants a better handling of its habitual drunks, it will have to do more than crack down on technically illegal releases by the police departinent. ${ }^{\mathrm{ut}}$

A more uncommon situation, but one involving greater likelihood of hardship to an innocent person, is that in which a person is arrested during late afternoon or evening. Despite the reasonableness of the arrest, subsequent events make clear his innocence. ${ }^{118}$ Again his appreciation of his legal "right," which he is not permitted to relinquish, ${ }^{110}$ to appear before a magis-

113 See text at note 23 supra.

114 CAL. Pen. Code $\S 647$ (11): "Every common drunkard . . . is a vagrant . . .."

115 And more than 50 percent of this department's total arrests are for drunkenness.

116 Hall, supra note 2 , at $359-362$.

117 As Alameda County is doing at its Santa Rita clinic.

118 E.g., see note 107 supra.

110 One department says it never makes releases under these circumstances; another says "seldom"; a third says "constantly." It must be considered that the third department's practice may be more liberal but also inay mean that it makes more arrests of innocent persons on barely tenable grounds to begin with. 
trate the next morning rather than to be immediately released without further inconvenience is apt to be less than overwhelming. Surely legalizing release by police in this situation is not open to the same criticisms that may be leveled at similar handling of drunkenness arrests. Any statutory provision which might be made could easily make it quite clear that release by the police following an arrest which was illegal in soine other respect would not have the effect of making the original arrest legal, but only of limiting the damages which might be recovered in a suit for false arrest.

\section{False Arrest Suits}

If officers charged with enforcement of the law are to proceed according to rules, there must be adequate redress available to the injured citizen when those rules are not obeyed. Otherwise the citizen can have no belief that police are subject to law as are other citizens. In particular, if certain traditional rights, such as the right to resist illegal arrest, ${ }^{120}$ are to be taken from the citizen, they should be supplanted by effective remedies. Citizens' suits for false arrest against police officers are not a satisfactory remedy at present. The general problem is far too large and complicated to be considered here, but any legislative examination of the law of arrest should include a good deal of thought as to how such actions could be made uniformly effective without also making them subject to abuse and excessive recoveries. ${ }^{121}$

There is little agreement as to the best means of accomplishing the desired result. Most police departments are content with the existing situation, under which liability for such claims falls on the offending officer. This is the view of department officials; patrolmen might dissent. Unfortunately, this is too often a remedy in name alone. Police officers' financial capacity to meet judgments is usually poor. It is axiomatic that smart policemen carry any considerable assets in their wife's name. ${ }^{122}$

One department believes the city should be liable and should carry insurance, but another objects that the "present distinction between proprietary and governmental operations of a inunicipality should be retained"123 and that the city's financial solvency would invite a multitude of speculative attempts to realize on ungrounded claims. This may be true, although an examination of cases shows the courts displaying remarkable solicitude for the interests of insurance and bonding companies. The defense frequently invoked is that unlawful acts are outside the scope of the officer's authority so that his principal cannot be liable. In other words, the more flagrant the abusive act, the less chance the citizen has of recovering from the bonding company. ${ }^{124}$

120 See text at note 92, supra.

121 A good discussion will be found in Hall, supra note 2, at 346-353.

122 See Bohlen and Shulman, The Effect of Subsequent Misconduct Upon a Lawful Arrest, 28 Cor. L. REv. 841, 844, n.11 (1928).

123 David, California Municipal Tort Liability, 7 So. CaLr. L. Rev. 295, 302 (1934).

12.t Hall, supra note 2 , at 350 . 
Ungrounded attempts to recover should be discouraged not by making recovery difficult or impossible regardless of the justice of the claim, but rather by a careful allocation of presumptions and burden of proof in such suits. A large district attorney's office believes it should be spelled out in the Penal Code that an officer is presumed to have acted in good faith in making an arrest, and the burden of proof should be on the plaintiff to show not only an illegal act but also malice. This would absolve the officer of liability where, for example, he had arrested the wrong person of two people with the same name. However, it would also make recovery almost impossible except where the officer's conduct had been so flagrantly outrageous that malice could be implied.

\section{Conclusion}

Most of the problems which have been considered were investigated by Professor Sam Bass Warner in 1939, and most of the proposals are those which he made on the basis of that investigation. ${ }^{125}$ The attempt has been made to relate these to the California law and experience. At the conclusion of the article in which Professor Warner originally described his investigation, he wrote:

To the public, all questions of the legality of police action may seem picayune beside those of how to eliminate "shakedowns" and the "third degree" ... Certainly one way to make the police more law-abiding ... is to instil in police officers a strong feeling that they, as guardians of the law, should obey it. This feehing cannot easily be instilled in officers who find that in many of the ways in which the law touches their duties, it is ridiculous, and that they cannot follow it and protect the public. Hence, legalizing proper police practices should prove a great help in building up an esprit de corps in police departments. ${ }^{126}$

This is the underlying argument behind all proposals for revision of the statutory rules concerning arrest: that we have not the right to criticize many of our police departments' illegal actions until we have given fair consideration to the anachronistic statutory fetters which we have permitted the passage of time to fasten on the police.

Keeping the law responsive to the goal of social justice through restraints on those to whom have been delegated powers capable of abuse is important. But so is keeping the law responsive to the needs of those who have been charged with important public duties. ${ }^{127}$ Obviously, powers and duties are inescapably united in our police forces. It will not do to assume that every limit placed on police powers 75 or 100 years ago must necessarily be inviolate. Respect for the sanctity of basic constitutional

125 Warner, Investigating the Law of Arrest, 26 A. B. A. J. 151 (1940).

126 Id. at 155 .

The "third degree" is not dealt with here for several reasons, one being tbat it may be attendant upon legal as well as illegal arrest. See Comments, 9 Sr. Jown's L. REv. 180 (1934), 7 Id. 60 (1932); National Commission on Law Observance and Enforcement, Report ON LAwIEsSNess IN LAW ENFORCEMENT (1931); Comment, 43 HaRv. L. Rev. 617 (1930).

127 It is unpleasant to hear an intelligent and thoughtful chief of police exclaim in weariness at the "stumbling blocks" thrown in the path of those hired to control and, if possible, chiminate crime: "Anybody who says that crime doesn't pay doesn't have the facts l" 